\title{
Giving credit where it's due
}

\author{
Following the recent decision in Murphy v Gooch, \\ Mark Pawlowski asks what principles govern entitlement \\ to an occupation rent when parties have separated
}

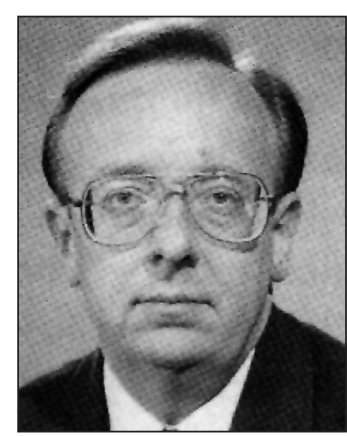

Mark Pawlowski is a barrister and professor of property law at the University of Greenwich

'The decision in Murphy confirms the modern trend of awarding occupation rent as a matter of course in cases where there has been a breakdown of the relationship and one party has left the other in sole occupation of the joint home.'

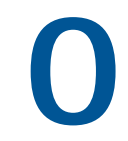

ccupation rent may be payable when one party has been prevented from living in a family home in which they have an interest and a right of occupation. Generally, consideration will be given to the payment of an occupation rent where the party in occupation has 'ousted' the other, as opposed to circumstances in which the party remaining in occupation did not seek the departure of the other party. An occupation rent may be payable by the party that remains in the home to compensate the ousted party for the loss of benefit of being able to live in the home.

There are two key questions when considering occupation rent:

(1) Is proof of ouster from occupation a prerequisite to an occupation rent?

(2) How is the size of the credit calculated?

Until recently, it was thought that entitlement to an occupation rent was governed by the doctrine of equitable accounting, which comprises a set of rules of convenience aimed at achieving justice between co-owners on separation. The normal practice has been to allow the occupying spouse (or partner) to take credit for repayments of the mortgage capital after separation, the interest element being set off against the liability to pay an occupation rent to the outgoing spouse.

The House of Lords' ruling in Stack $v$ Dowden [2007], however, altered the basis on which the relevant principles are to be applied. Their Lordships unanimously concluded that the court's power to order payment to a co-owner in occupation is no longer determined by the doctrine of equitable accounting but is instead governed by the statutory principles set out in $\mathrm{s} 15$ of the Trusts of Land and Appointment of Trustees Act 1996 (the 1996 Act).

The recent decision of the Court of Appeal in Murphy $v$ Gooch [2007] is the first case at appellate level to consider this new approach involving a coowner's entitlement to credit from her former partner, who remained in sole occupation of the joint home.

\section{Previous case law}

Earlier cases have established that an occupational rent will be charged where the party in occupation has actually or constructively excluded the other part from occupation: see Dennis v McDonald [1982]. However, the obligation to pay an occupation rent has not been restricted to so-called 'ouster' cases, in which a marital association has broken down and one party has been deliberately driven out from the family home.

The adoption of a less rigid approach is, perhaps, best illustrated by the decision of Millett J (as he then was) in Re Pavlou [1993] - where he concluded that an enquiry into the payment of an occupational rent could be made in any case where it was necessary to do broad justice between the parties. In his view, a 'forceful exclusion' was by no means conclusive and, in the context of the matrimonial home where the marriage had ended:

\footnotetext{
... the party who leaves the property will, in most cases, be regarded as excluded from the home, so that an occupational rent should be paid by the co-owner who remains.
}

Thus, in his view, the presentation of a divorce petition by the occupying spouse would normally be enough to signify a 
refusal to take the outgoing partner back into the matrimonial home and, therefore, a willingness to pay an occupation rent from the date of its issue. On the other hand, such a liability would clearly be inappropriate in circumstances where a spouse left voluntarily and would be welcome back by the occupying partner so as to be able to enjoy their right to occupy.

The more relaxed approach towards charging occupation rent in order to do equity between the parties is also evident in Re Byford [2003], where the court ordered the payment of an occupation rent in favour of the husband's trustee in bankruptcy despite there being no marriage breakdown or ouster.

\section{Stack v Dowden}

In Stack the parties had been living together as man and wife for a number of years and had four children. Their house had been bought as a home for them both and the children. When the parties eventually separated, three of the children were still minors.

Mr Stack obtained rented accommodation elsewhere and Miss Dowden continued to be responsible for the upkeep and outgoings on the home until it was sold. Significantly, Mr Stack had nothing to pay in respect of the upkeep of the home until he was able to realise his share on the sale.

\section{House of Lords decision}

On these facts, the majority of the House of Lords (Lord Neuberger dissenting) refused to make an order requiring the payment of an occupation rent to Mr Stack to compensate him for his exclusion.

\section{Statutory basis for the ruling}

All members of the House of Lords concluded that the appropriate approach was to look at the relevant provisions of the 1996 Act. In this connection, s12(1) gives a beneficiary, who is beneficially entitled to an interest in land, the right to occupy it if the purpose of the trust is to make the land available for their occupation. Section 13(1) and (2) gives trustees the power to exclude or restrict this entitlement so long as it is exercised reasonably. The trustees also have power, under s13(3), to impose conditions on the occupier, including the payment of outgoings or expenses in respect of the land and paying compensation to a person whose right to occupy has been excluded or restricted: see s13(5) and (6).

Significantly, both trustees and beneficiaries can apply to court for an order declaring the nature and extent of a person's interest in the land subject to the trust and it is here that the court's statutory jurisdiction to take accounts between excluded from the home and that Miss Dowden should pay him $£ 900$ per month as recompense for his cost of renting alternative accommodation. When that order expired, they failed to reach further agreement and so the decision whether to require compensation became a matter for the court under

\section{The main consideration of the majority in refusing compensation in Stack was the need for the children to remain in their home, under the care of the mother, until the house was sold.}

co-owners is limited by reference to a number of important factors set out in s15(1), namely:

(a) the intentions of the person(s) who created the trust;

(b) the purposes for which the property subject to the trust is held;

(c) the welfare of any minor who occupies or might reasonably be expected to occupy the property as their home; and

(d) the interests of any secured creditor of any beneficiary.

In addition, in relation to any application relating to the exercise by trustees of the powers conferred by s13, the court must also have regard to the wishes of each of the beneficiaries who is entitled to occupy the land: see s15(2). In the case of other applications, the circumstances and wishes of any beneficiaries of full age entitled to an interest in possession must also be considered: see s15(3). The upshot of the foregoing is that the court is no longer concerned only with considerations relevant to achieving justice between the parties, but must take on board (in achieving a just result) the wider criteria set out in s15 - in particular, the welfare of any minors, the interests of any secured creditors and the circumstances and wishes of the beneficiaries.

In Stack, both parties had the right to occupy the family home. As trustees, they initially agreed, pursuant to s13(1) of the 1996 Act and by means of a consent order, that Mr Stack should be s14(1). The main consideration of the majority in refusing compensation was the need for the children to remain in their home, under the care of the mother, until the house was sold. The conduct of the sale was with her and there was nothing to suggest she was delaying a sale. Lord Neuberger, however, dissented on this point, concluding that Miss Dowden had excluded Mr Stack against his will, forcing him to incur the cost of alternative accommodation. Moreover, in his view, the agreed payment of $£ 900$ per month (as a quid pro quo for his exclusion) governed the matter as circumstances had not really changed after the expiry of the consent order.

\section{Murphy v Gooch}

Here the parties (an unmarried couple) had bought a house as their family home in 1991. Two years later, their relationship broke down and Miss Murphy left the property. Since then, Mr Gooch had made all payments on the house, including interest instalments under the mortgage, rent paid to a housing association (which owned a share in the property) and payments under a mortgage policy.

Miss Murphy now sought a declaration that she and $\mathrm{Mr}$ Gooch were entitled to the property as tenants in common in equal shares, and an order

\section{Reference point}

Readers interested in the Stack $v$ Dowden judgment will find an analysis of the case by Elissa Da Costa in the June 2007 issue of Family Law Journal. 


\section{PROPERTY}

for sale. She also sought a further order that, if Mr Gooch continued in occupation of the property, his continued occupation should be subject to the condition (inter alia) that he should pay her such sum as the court thought fit as compensation for her exclusion from the property.

\section{First instance decision}

At first instance, the judge held that $\mathrm{Mr}$ Gooch was entitled to credit in respect of the payments he had made in respect of the various outgoings on the house, but that there should be offset against those credits one-half of all the payments by way of an occupation rent.

\section{Appeal decision}

On appeal, the first substantive issue was whether Miss Murphy's claim for
The wider ambit of relevant considerations means that the task of the court must now be, not merely to do justice between the parties, but to do justice between the parties with due regard to the relevant statutory considerations...

Applying, therefore, the criteria set out in s15(1) and mentioned above, Lightman J noted that both parties (as creators of the trust) had bought the house as their joint home (a purpose that had failed since 1993 when they separated) and that Mr Gooch had, since that date, occupied the property alone as his home. So far as the interests of any creditor were concerned, it was apparent that the mortgagee's interest would not be prejudiced by the outcome of the proceedings and, in particular, the success (or otherwise) of

\section{In Murphy it was apparent that Miss Murphy had left the property on the breakdown of her relationship with Mr Gooch and, accordingly, she was to be regarded as constructively excluded from the date of separation.}

an occupation rent was barred by reason of an absence of any ouster from the premises. On this point Lightman J (giving the judgment of the court) concluded that a court could order credit for occupation rent if it was just to do so, regardless whether there was proof of ouster.

In reaching this conclusion, Lightman $\mathrm{J}$ was mindful of the earlier cases, notably Pavlou and Byford, which made it clear that 'an occupation rent may be ordered in any case where this is necessary to do broad justice or equity between the parties'. In any event, even if ouster were necessary, it was apparent that Miss Murphy had left the property on the breakdown of her relationship with $\mathrm{Mr}$ Gooch and, accordingly, she was to be regarded as constructively excluded from the date of separation.

\section{Calculation of credits}

This then left the question of calculation of the parties' respective credits. On this point, Lightman J concluded that the statutory principles stated in s15(1) of the 1996 Act had to be applied:
Miss Murphy's claim to set off occupation rent against Mr Gooch's outgoings or a sale of the property.

The final consideration related to the circumstances and wishes of the parties. In this connection it was apparent that, while both were in financial difficulties and Miss Murphy wanted a sale, $\mathrm{Mr}$ Gooch was anxious to avoid a sale of his longstanding home. Taking everything into account, his Lordship concluded that there was no good reason for limiting Miss Murphy's right to a set-off to only one-half of the credits to which Mr Gooch was entitled. Accordingly, he ordered an entitlement to a set-off against the entirety of the credits representing costs,

\section{Re Byford}

[2003] EWHC 1267 (Ch)

Dennis v McDonald

[1982] Fam 63

Murphy v Gooch

[2007] EWCA 603

Re Pavlou

[1993] 1 WLR 1046

Stack v Dowden

[2007] UKHL 17

expenses and outgoings met by $\mathrm{Mr}$ Gooch during the whole period of his continuing (sole) occupation.

\section{Conclusion}

Although the statutory powers contained in ss12-15 of the 1996 Act have now replaced the old doctrine of equitable accounting, it is unlikely that this will lead to different results in practice. This was the conclusion reached by Baroness Hale in Stack. Lord Neuberger was more emphatic, suggesting that it would be a 'rare case' where the statutory criteria would produce a different outcome from that which would have resulted under the previous case law applying equitable principles. The recent decision in Murphy bears this out - although the matter was decided by reference to the statutory principles, Lightman J considered a like result would have followed under the earlier law.

The decision in Murphy confirms the modern trend of awarding occupation rent as a matter of course in cases where there has been a breakdown of the relationship and one party has left the other in sole occupation of the joint home.

The rationale here is that the absent partner can no longer realistically occupy the property and they must therefore incur the expense of securing another home. It is enough, therefore, that the parties' circumstances will make shared occupation impossible from a practical standpoint.

\section{Key points}

- The court may order payment of an occupation rent regardless of whether there is proof of ouster.

- The court's power to order payment of an occupation rent is no longer governed by the doctrine of equitable accounting.

- The statutory criteria set out in $s \mid 5$ of the Trusts of Land and Appointment of Trustees Act 1996 now apply in achieving a just result between the parties. 